\title{
PHYSIOLOGICAL, ENZYMATIC, AND SANITARY QUALITY OF WHEAT SEEDS TREATED WITH ZINC SULFATE DURING STORAGE
}

\author{
Lilian Tunes ${ }^{1}$, Elisa Lemes ${ }^{1}$, Andréia Almeida ${ }^{1}$, Gizele Ingrid Gadotti ${ }^{1}$, Daniel Fonseca ${ }^{1}$, \\ Marlove Muniz ${ }^{2}$ \\ ${ }^{1}$ Universidade Federal de Pelotas, E-mail: lilianmtunes@yahoo.com.br, lemes.elisa@yahoo.com.br, \\ andreiasalmeida@yahoo.com.br, gizele.gadotti@ufpel.edu.br, danielfonseca30@yahoo.com.br, \\ ${ }^{2}$ Universidade Federal de Santa Maria, E-mail: marlovemuniz@yahoo.com.br
}

\section{ABSTRACT}

The objective of this study was to evaluate the effect of zinc coated seeds on the enzymatic and sanitary aspects during storage. One concluded that wheat seed coating with zinc at doses of $3 \mathrm{~mL}$ to $4 \mathrm{~mL}$ of $\mathrm{ZnSO}_{4}$ support maximum expression of physiological quality, in addition to wheat seed coating with zinc sulfate is effective during the period of six months of storage. There are variations in expression pattern of EST and GOT enzymes between wheat seeds and seedlings, at different doses of zinc sulfate during storage. Zinc supplied via seeds, associated with fungicide and polymer, results in a lower incidence of fungi in seeds throughout storage period.

Keywords: Triticum aestivum, seed treatment, seed vigor

\section{QUALIDADE FISIOLÓGICA, ENZIMÁTICA E SANITÁRIA DE SEMENTES DE TRIGO TRATADAS COM SULFATO DE ZINCO DURANTE O ARMAZENAMENTO}

\section{RESUMO}

O objetivo do trabalho foi avaliar o efeito do recobrimento de sementes de trigo com zinco na análise enzimática e sanitária durante o armazenamento. As doses de 3 e $4 \mathrm{~mL}$ de $\mathrm{ZnSO}_{4}$ auxiliam na maximização da expressão da qualidade fisiológica das sementes de alto e baixo vigor, respectivamente. Há variações no padrão de expressão das enzimas EST e GOT entre sementes e plântulas, nas diferentes doses de sulfato de zinco, durante o armazenamento. Zinco associado com fungicida e polímero apresentaram menor incidência de fungos ao longo do período de armazenamento.

Palavras-chave: Triticum aestivum, tratamento de sementes, vigor 


\section{PHYSIOLOGICAL, ENZYMATIC AND SANITARY QUALITY OF WHEAT SEEDS TREATED WITH \\ ZINC SULFATE DURING STORAGE}

\section{INTRODUCTION}

Enzymes related to the physiological quality of seeds are the most researched of those acting in the respiratory process, such as malate dehydrogenase, those involved in the metabolism of the nitrogen-carbon bond, such as glutamate dehydrogenase, and those with specific functions in lipids metabolism and the related disruption of the membrane system, such as esterase (CARVALHO \& NAKAGAWA, 2000). Malate dehydrogenase is an enzyme activated primarily during the cellular respiration process, regenerating one molecule of oxaloacetate from the oxidation of one molecule of malate, keeping the oxidative flow during the citric acid cycle (Krebs cycle), characteristic of stages in respiration process. During seed germination, this enzyme is also active in the gluconeogenesis process, responsible for sucrose generation from triacylglycerol present inside oleosomes, in seed reserve tissues.

The largest contribution of zinc in the metabolic processes of plants is a component of several enzymes: dehydrogenases, proteinases, peptidases, and fosfohidrolases. Lindasay (1972) reported that a basic function of zinc is related to carbohydrates, proteins, and phosphates metabolism and also in auxin RNA and ribosome formation.
There is evidence that zinc influences membrane permeability in the stabilization of cellular components. In addition, support in substance synthesis that acts on growing and enzyme systems, becomes essential for activation of certain metabolic reactions.

Another important factor that must be analyzed during the storage period is the sanitary quality of wheat seeds, even the seeds that have been covered with the use of pesticides. Occurrence of diseases is a major limiting factor to production. The wheat plant, at any stage of development, is subject to diseases that reduce both seed quality and the final quality product. Direct losses caused by diseases in wheat, include reduction in plant stand, stained grains, number and/or grain size, and reduction in overall production efficiency of these plants (MIURA, 2002). According to Lima et al.(2006), microorganisms' incidence in seeds is responsible for pre-emergence death, seedlings in field, vigor and germination loss in storage, with consequent reduction in field final stand. Many pathogens may be associated with wheat seeds, most of which are of fungal origin (REIS \& CASA, 1998). Among the most important fungi, the genera Fusarium, Alternaria, Bipolaris, Drechslera, Septoria, Ustilago and Tilletia (REIS \& CASA, 1998) 
invade seeds still in the field, and require, relative humidity around 90 to $95 \%$ for growth, which, according to Dhingra (1985), represents a water content of $25 \%$ in starchy seeds, such as wheat. If there is a reduction in water content, it can paralyzethe development of these fungi, and there are no new invasions (MILLS \& WALLACE, 1992).

Therefore, it is necessary to research methods to support maximizing wheat seeds quality. Increasing quality demands of the market have led to an option for monitoring seeds, relating seed treatment with micronutrients (provision of a deficiency), storage as a method of quality, and fast and effective control through evaluations with isoenzymes and sanitary quality. This research aimed to evaluate the effect of zinc coating on wheat seeds, through enzymatic and health aspects during storage.

\section{MATERIAL AND METHODS}

We used two seed lots of wheat; one with high quality and the other with low quality. Commercial product Quimifol Seed $78^{\circledR}$ was used with a source of zinc, zinc sulfate (ZnSO4), in which each $100 \mathrm{~mL}$ of this solution provides $78 \mathrm{~g}$ of zinc. One was tested with five levels $(0,1,2,3$, and $4 \mathrm{~mL}$ $\mathrm{ZnSO} 4 . \mathrm{kg}^{-1}$ seed), and $3 \mathrm{~mL}$ of fungicide (thiram + carboxim), $0.8 \mathrm{~mL}$ of polymer Poly Seed $\mathrm{CF}^{\circledR}$ (high quality lot) or Collor Seed ${ }^{\circledR}$ polymer (low quality lot) and enough water to complete spray a volume of 15 $\mathrm{mL} . \mathrm{kg}^{-1}$ seed was also added. The use of different polymers was only to distinguish lots by color.

Seed coating was carried out manually using $0.3 \mathrm{~kg}$ of seeds per experimental unit, with a product mixture made in plastic bags and after seeds were added. Seeds were mixed until reaching the complete distribution of products and seed coverage. Then, coated seeds were placed to dry at room temperature for 24 hours and after that they were stored in uncontrolled conditions for a period of six months.

Tests were conducted for evaluation of physiological, enzymatic, and sanitary quality of wheat seeds coated with zinc, during the six months storage at ambient temperature and uncontrolled relative humidity. Evaluations were performed immediately after coating (initial analysis) and every three months of storage.

Quality during storage was evaluated by germination and first count of germination. Germination (G) was performed with four replicates of 100 seeds per plot. The seeds were placed on a wet germitest paper roll, adding 2.5 times the 


\section{PHYSIOLOGICAL, ENZYMATIC AND SANITARY QUALITY OF WHEAT SEEDS TREATED WITH ZINC SULFATE DURING STORAGE}

weight of the dry paper roll of distilled water. Rolled paper was placed inside plastic bags and kept in a germination chamber, set at $20^{\circ} \mathrm{C}$ and the seedling count was evaluated eight days after sowing (BRASIL, 2009). First count of germination (FCG) was conducted together with a germination test, computing the mean percentages of normal seedlings after four days of test setup. Results were expressed as a percentage of normal seedlings.

For isoenzyme differentiation, isoenzymes were analyzed: esterase (EST EC 3.1.1.1) and glutamate oxaloacetate transaminase (GOT - EC 2.6.1.1), for all treatments. The seeds were placed on wet germitest paper roll and after four days the seedlings were collected for extraction. Also, it was performed with dry seeds, removed from storage and taken for extraction. For this, we analyzed ten seeds and seedlings, randomly collected, and macerated in a porcelain mortar, for each treatment and repetition. From each sample, $200 \mathrm{mg}$ of plant extract were placed in eppendorf tubes, plus extraction solution (gel buffer $+0.15 \%$ 2-mercaptoethanol) in proportion 1:2 (w/v). Electrophoresis was performed in $7 \%$ polyacrylamide gels, placing $20 \mu \mathrm{L}$ of each sample in holes made with acrylic stick. Three applications (repetitions) for each sample were performed. Enzyme patterns were analyzed by buffers system described by Scandalios (1969). Gels were placed in vertical electrophoretic tanks, kept in cold storage at a temperature between 4 and $6{ }^{\circ} \mathrm{C}$. Electrophoretic migrations were performed with a potential difference of $10 \mathrm{~V} . \mathrm{cm}^{-1}$, until front line, formed by bromophenol blue, still reached $9 \mathrm{~cm}$ from application point. Gels were revealed as Scandalios (1969) and Alfenas (1998). Electrophoresis gels were fixed in 5-5-1 solution, distilled water: methanol: acetic acid.

Evaluation of wheat seed sanitary quality was performed by seed sanitary testing, "Blotter test". We used 200 seeds of each treatment, divided into four subsamples of 50, placed in plastic boxes like "gerbox", previously sterilized with alcohol and hypochlorite $(1 \%)$ for one minute, under two pieces of filter paper moistened with sterile distilled water. Seeds were incubated at 25 ${ }^{\circ} \mathrm{C}, 12 \mathrm{~h}$, and light for $24 \mathrm{~h}$. Then, for germination inhibition, seeds were subjected to the freezing method for $24 \mathrm{~h}$. After this procedure, seeds were incubated at $25^{\circ} \mathrm{C}$ for seven days with $12 \mathrm{~h}$ light according to methodology proposed by Brasil (2009). Analyses were performed with a support microscope for observation of morphological structures of fungi, which were identified at 
the genus level, with the help of the specialized bibliography of Barnett \& Hunter (1998), by determining seeds percentage contaminated by fungi.

Experimental design was completely randomized with four replications. Averages were subjected to ANOVA and regression. Statistical analysis was performed using statistical package Sisvar (FERREIRA, 2000). Results interpretation of isoenzymes was based on visual analysis of electrophoresis gels, taking into account presence/absence, and intensity of each electrophoretic band in each isoenzyme system evaluated.

\section{RESULTS AND DISCUSSION}

Data from the initial germination periods of three and six months after storage were recorded (Figures $1 \mathrm{~A}$ and 1B). The high quality lot showed no significant difference between germination potential doses of zinc sulfate tested throughout the storage period (Figure 1A). These results agree with those found by Ohse et al. (2000) to conclude that coating rice seeds with zinc did not provide differences in germination. Likewise, Fungueto (2010) analyzed rice seed coatings with zinc source, fungicide, and polymer and found no difference in germination. However, in sorghum seeds treated with zinc, Yagi et al. (2006) reported a reduction in percentage of germination. Trentini et al. (2005) found no significant differences in germination of soybean seeds coated with AGL 205 film and fungicide.

Seed germination of the low quality lot (Figure 1B) showed no difference in initial data evaluation. However, in periods of three and six months of storage, germination potential of seeds grew with the increasing $\mathrm{ZnSO}_{4}$ doses in seeds. Seeds have expressed their full potential in a dose of 4 $\mathrm{mL}$ of $\mathrm{ZnSO}_{4}$ in three and six months of storage. Data on the first count of germination test for seeds with high and low quality lots were registered (Figure $1 \mathrm{C}$ and 1D). Initial data evaluation, for both lots, showed no difference in germination percentage. However, it showed variation, within three months of storage.

After three months of storage, the high quality seed lot showed significant results at a dose of $3 \mathrm{~mL}$ of $\mathrm{ZnSO}_{4}$, when compared to other doses tested and controlled. However, for the lower quality seed lot, with increasing dose in the zinc coating the seeds improved early development of seedlings in the germination test (i.e., $4 \mathrm{~mL}$ of $\mathrm{ZnSO}_{4}$ dose was considered the best in both periods storage analyzed). In seeds, the majority of zinc is 
found in protein bodies, mainly in phytic acid form, are quickly hydrolyzed in the germination process, and, thus available to seedlings (REZENDE et al., 2009).

Studies of enzymatic processes are one way of assessing seed quality. Isozyme markers have been used in viability studies, because they are efficient for knowledge of important events of life time, deteriorative changes and seeds death. From analysis of four enzyme systems used, it was possible to check that there was significant variation in isoenzyme expression intensity, according to zinc sulfate doses applied to seeds during storage (Figure 2). Patterns of four isoenzyme systems analyzed showed variations in expression, because of this, each system was discussed and analyzed individually. Esterase is an enzyme responsible for metabolism of membrane lipids during seed germination, so for these results, it is observed that there was positive effect of applied product. By observing enzyme esterase pattern (EST) in seeds during storage, it was noted that there is novariation of its expression in tested doses of zinc sulfate in seeds, in both lots (Figure 2 $\mathrm{Aa}, \mathrm{Ba}, \mathrm{Ca}, \mathrm{Ab}, \mathrm{Bb}$ and $\mathrm{Cb}$ ). However, for seedlings, this enzyme showed more intense bands at a dose of $4 \mathrm{~mL}$ of $\mathrm{ZnSO}_{4}$ treatment of wheat seeds, in three and six months storage for high quality lot (Figures 2Ba and $\mathrm{Ca})$.

These results agree with those reported by Diniz et al. (2009), who observed increased intensity of bands in lettuce seeds coated with zinc during storage and Tunes et al. (2009) who reviewed progress in expression of this enzyme bands in barley seeds during storage for six months.

For low quality seed lot, bands intensity derived from seedlings was decreasing with increasing concentration of zinc micronutrient (Figures $2 \mathrm{Bb}$ and $\mathrm{Cb}$ ), contradicting the study in seedling. In tomato seeds, increased activity can lead to reductions in quality, because, according to Santos et al., (2004) esterase is an enzyme involved in esters hydrolysis, being directly linked to lipid metabolism and membrane degenerative process. According to Vieira et al. (2006) esterases have specific functions in lipid metabolism and can be used as markers of seeds deterioration process. Thus, it is important to use molecular markers for assessing seeds quality. Zinc facilitates the synthesis of substances that act on growth and enzyme systems, which is essential for activation of certain metabolic reactions. 

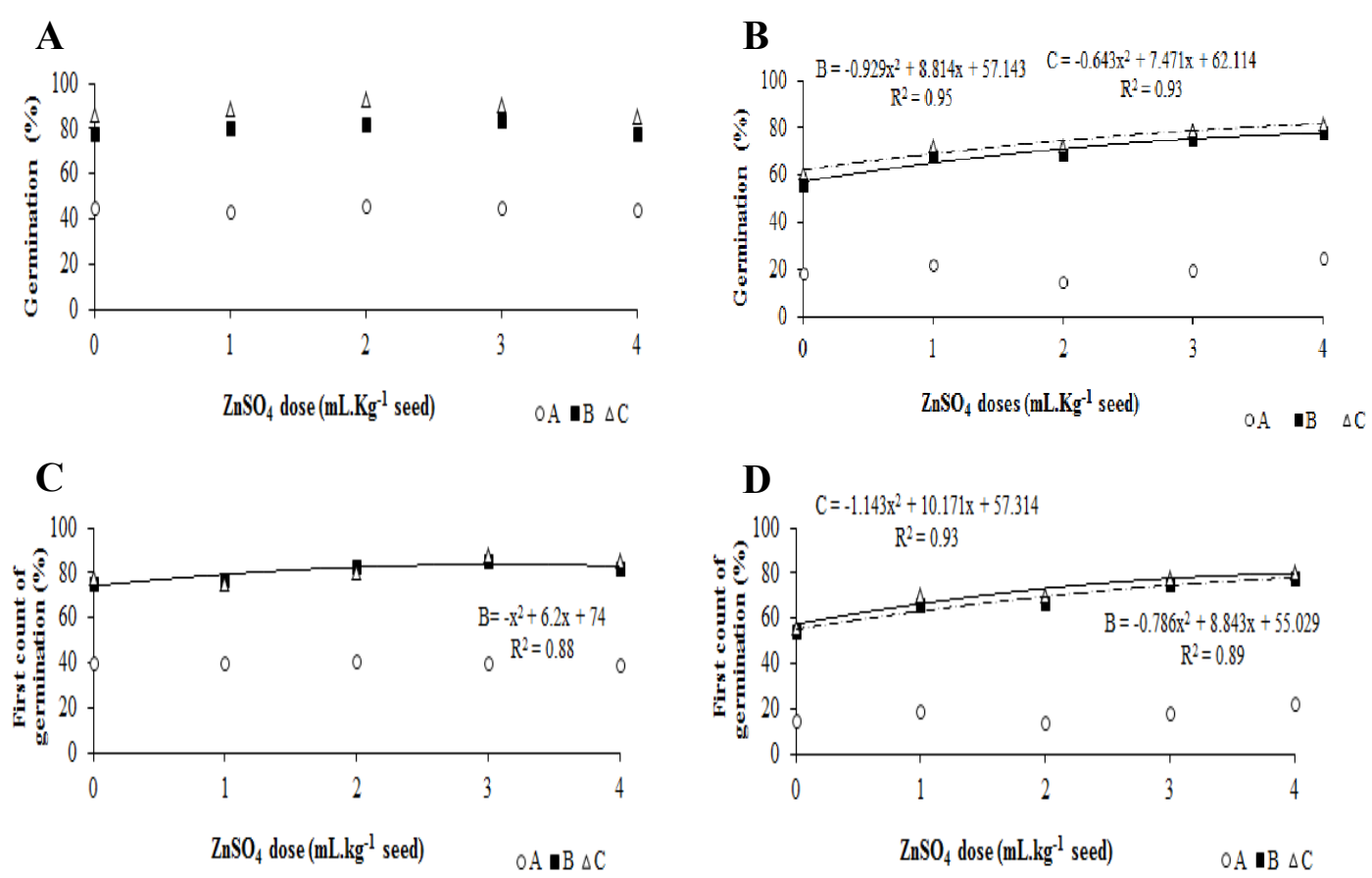

Figure 1. Germination (A and $\mathrm{B}$ ) and first count of germination (C and D) of wheat seed, high and low quality lot, after coating with different doses of $\mathrm{ZnSO} 4$. A) Initial data of germination; B) Three-month storage, C) Six-month storage. Pelotas, RS, 2014.

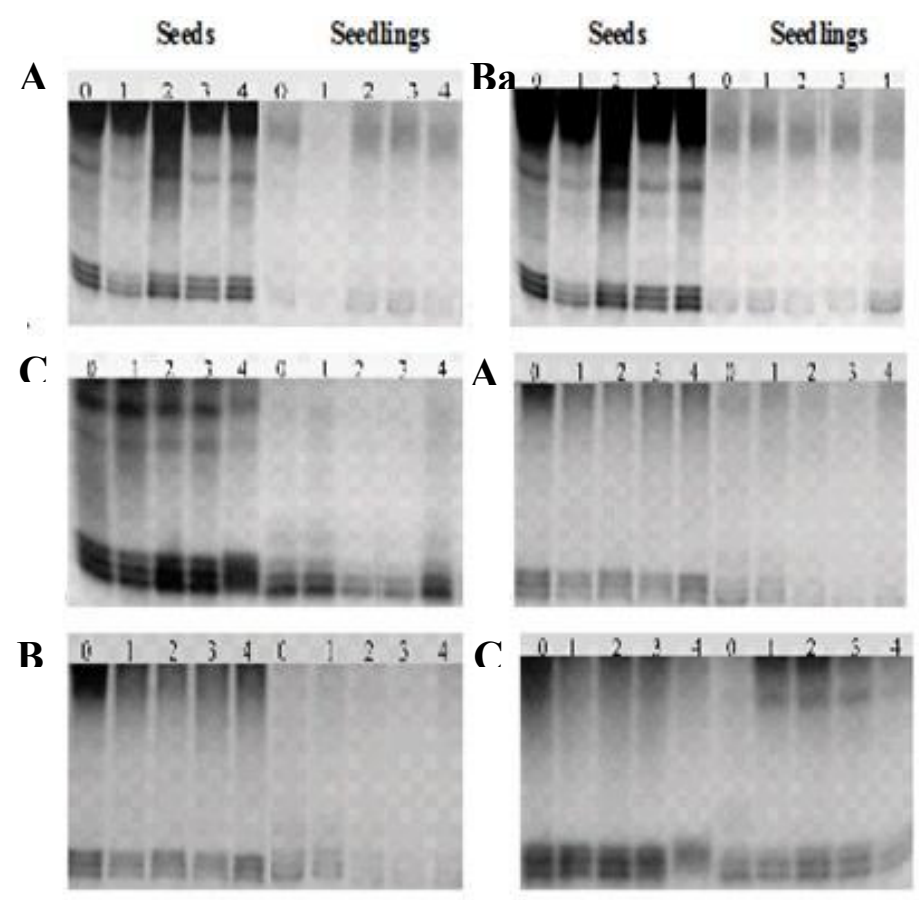

Figure 2. Electrophoretic pattern obtained with esterase isoenzyme system (EST) on high and low quality lots, after coating with different doses of $\mathrm{ZnSO}_{4}$. A) initial data for germination, B) three months of storage, C) six months of storage. a) high quality lot, b) low quality lot. Pelotas, RS, 2014. 


\section{PHYSIOLOGICAL, ENZYMATIC AND SANITARY QUALITY OF WHEAT SEEDS TREATED WITH ZINC SULFATE DURING STORAGE}

Enzyme GOT has a fundamental participation in protein metabolism, not only during germination but throughout lifecycle plant. Analyzing gels of glutamate oxaloacetate transaminase system (GOT), it was observed variation of bands intensity in initial data of evaluation of high quality seed lot (Figure 3Aa). For seeds of the low quality lot, it occurred intensity in first band (dose zero) throughout storage period, compared different doses of zinc sulfate applied to wheat seeds (Figures $3 \mathrm{Ab}, \mathrm{Bb}$ and $\mathrm{Cb}$ ). For seedling of high quality lot, there was a greater expression of GOT with increasing zinc concentration and during storage (Figures 3Aa, $\mathrm{Ba}$ and $\mathrm{Ca}$ ). Also, seedlings of low quality lot showed a greater intensity of bands in the higher dose of $\mathrm{ZnSO}_{4}$ on initial data evaluation and after six months of storage (Figures $3 \mathrm{Bb}$ and $\mathrm{Cb}$ ). In three months of storage there was no visual variation of enzyme expression (Figure $3 \mathrm{Bb})$.

This enzyme is responsible for amino acids oxidation, providing energy to Krebs cycle or $\alpha$-ketoglutarate reduction for new amino acids synthesis, as a source of energy to developing embryo. Tunes et al. (2010) found an increase of enzyme GOT bands to seeds deterioration. According to Tunes et al. (2010), these changes in bands expression are due to increase in metabolic activity with deteriorating process. According to Brandão Junior et al. (1999), this enzyme participates in degradation process and amino acids synthesis play an important role in seed germination, which confirms the results obtained in this work. Because this enzyme is directly involved in nitrogen metabolism, it is possible that variations occur as amino acids synthesis and degradation, during germination process and storage.

Factors limiting cultivation of wheat in Brazil, without doubt, include diseases. A seed of high physiological and sanitary quality is extremely important for establishment and development culture in the field. Thus, the seed testing, focused on sanitary seed quality of a sample represents a tool of great importance in seed certification, improving diagnosis and routine laboratory analysis. Data on sanitary seeds during the storage period for the high quality lot were registered (Figure 4Aa, 4Ba e 4Ca). Fungi found in wheat seeds during six months of storage were Fusarium sp., Alternaria sp., and Penicillium sp. In the initial data, seeds subjected to zero doses showed $45 \%$ of Fusarium sp.

At three months of storage, untreated seeds showed a reduced incidence of Fusarium sp. of $66.7 \%$, an incidence rate of 
$12 \%$ by Penicillium sp., and $15 \%$ by Alternaria sp. However, Alternaria sp. remained present at all doses, but with reduced incidence of $46.5 \%$ for doses of 1 , 2 , and $4 \mathrm{~mL} \mathrm{ZnSO}_{4}$, and $66.7 \%$ for the dose of $3 \mathrm{~mL}$ of $\mathrm{ZnSO}_{4}$. Within six months of storage, no difference was detected between different doses of $\mathrm{ZnSO}_{4}$, both for field and storage fungi (Figures 4Aa, 4Ba e 4Ca). All treatments were effective in controlling Penicillium sp., Fusarium sp. and Alternaria sp., with possible elimination of these fungi in seeds at storage ending, thus showing efficiency of treatment with zinc and confirming that seed coating did not affect efficiency of fungicide treatment. Probably, addition of polymer has promoted a toxic effect or formation of a mechanical barrier, which may have hindered fungi development and facilitated direct contact of product (fungicide + zinc) with seeds. When testing polymers application in chemical treatment of soybean seeds, Reis et al. (2005) found that their addition allows a better distribution and adhesion of chemicals on seed, which made treatment more efficient and allowed reduction of pathogens from seeds.

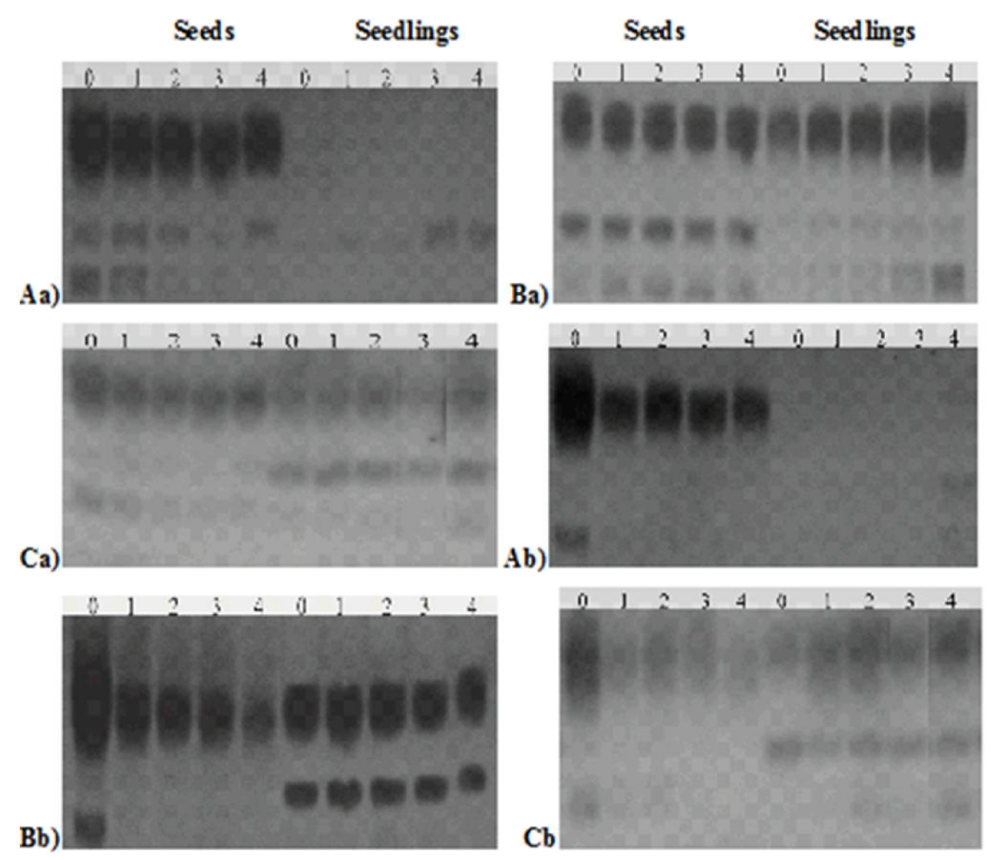

Figure 3. Electrophoretic pattern obtained with glutamate oxaloacetate dehydrogenase (GOT) on high and low quality lots, after coating with different doses of $\mathrm{ZnSO}_{4}$. A) initial data for germination, B) three months of storage, C) six months of storage. a) high quality lot, b) low quality lot. Pelotas, RS, 2014. 
However, according to Henning et al. (2003), polymers should only be used in conjunction with fungicides, since they do
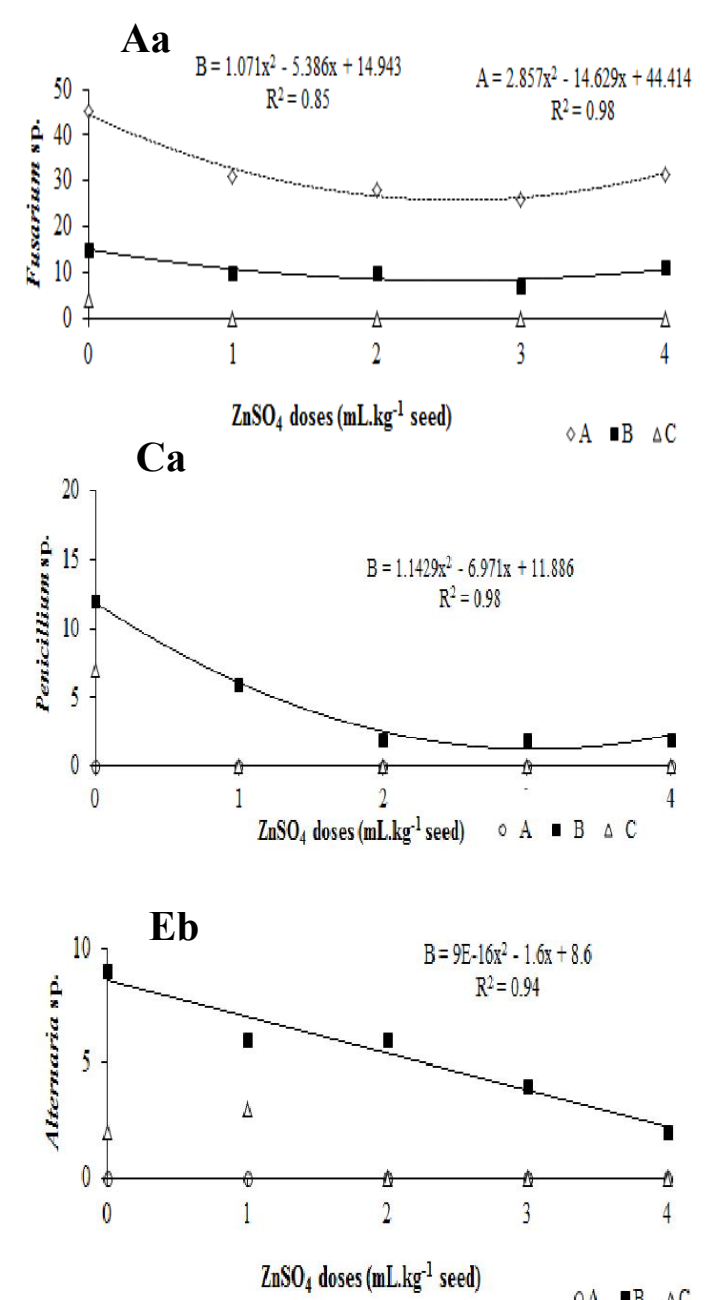

ZnSO $0_{4}$ doses (mL.kg $g^{-1}$ seed)

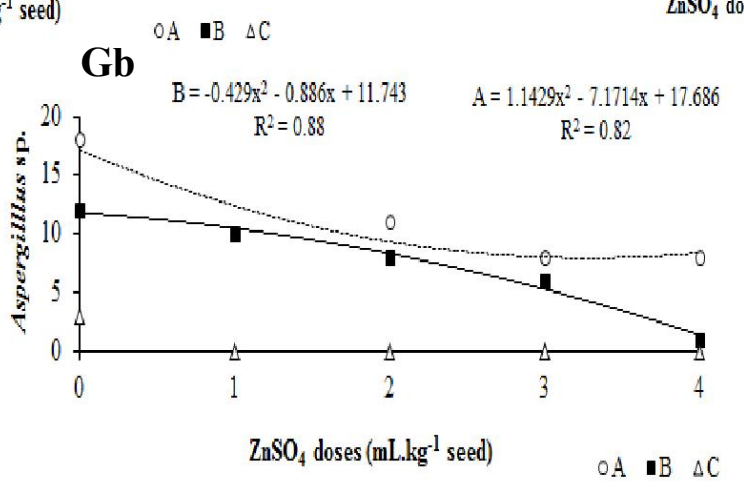

Figure 4. Sanitary seed testing in wheat seeds, high quality lot ( $\mathrm{Aa}, \mathrm{Ba}$ and $\mathrm{Ca}$ ) and low quality lot ( $\mathrm{Db}, \mathrm{Eb}, \mathrm{Fb}$ and $\mathrm{Gb})$, after coating with different doses of $\mathrm{ZnSO}_{4}$. A) initial data for germination, B) three months of storage, C) six months of storage. a) lot of high quality, b) lot of low quality. Pelotas, RS, 2014. 
Fungi found in low quality lot wheat seeds during six months of storage were Fusarium sp., Alternaria sp., Penicillium sp. and Aspergillus sp. In initial evaluation of low seed quality (Figures $4 \mathrm{Db}, 4 \mathrm{~Eb}, 4 \mathrm{Fb}$ and $4 \mathrm{~Gb})$, it is necessary to show that contaminated seed number by Penicillium sp. $(29 \%)$ was higher than incidence of another fungi [Aspergillus sp. (18\%) and Fusarium sp. (12\%)], which seems to have caused more negative effect on seeds metabolism.

Within three months of storage, three fungi found in initial analysis, remained in untreated seeds, but with lower incidence: Penicillium sp. (10\%) and Aspergillus sp. $(12 \%)$. This lot was also found within three months of storage, Alternaria sp., which had not been previously detected, with an incidence of $6 \%$ in untreated seeds. Alternaria sp. was also found with an incidence of $6 \%$ at doses of 1 and $2 \mathrm{~mL}, 4 \%$ at a dose of $3 \mathrm{~mL}$ and $2 \%$ at a dose of $4 \mathrm{~mL}$. In six months of storage, it was not found incidence of fungi between different doses of zinc sulphate applied to wheat seeds.

The results of this study suggest that, depending on enzyme system used, there is differentiation of proteins. As a result, joint analysis of several isozyme systems is recommended to check changes that occur inside seeds, subject to some type of treatment that influence quality. However, expanded use of biochemical markers to evaluate seeds physiological potential, still requires further study until it is established as a tool in quality control of seeds programs.

Mineral nutrition, as environmental factors, can be manipulated with relative ease to disease control. However, it is necessary a detailed knowledge of how mineral nutrients increase or decrease plants resistance (MARSCHNER, 1995). Low zinc levels in seed can result in tissues unable to grow normally, leaves may become necrotic, flowering and grain filling can be reduced. This deficiency can also be detected at cellular level, through malformation of organelles such as chloroplasts and mitochondria and cause further problems in cell division and twisted roots with tips expanded (MALAVOLTA, 2006) and thus become susceptible to pathogens. Pathogens reduction in seeds due to the effect of zinc, is a result of the influence of specific forms of this nutrient in different metabolic pathways, thereby altering plant constituents.

\section{CONCLUSIONS}

There are variations in expression pattern of the enzymes esterase and glutamate oxaloacetate transaminase 
between wheat seeds and seedlings, in different doses of zinc sulfate during storage.

Zinc supplied via seeds, associated with fungicide and polymer, results in a lower incidence of fungi in seeds throughout storage period.

\section{REFERENCES}

ALFENAS, A.C. 1998. Eletroforese de isoenzimas $\mathrm{e}$ proteínas afins: fundamentos e aplicações em plantas e microrganismos. Viçosa: Universidade Federal de Viçosa. 574p.

BARNETT, H.L.; HUNTER, B.B. 1998. Illustrated genera of imperfect fungi. St Paul, Minnesota: APS Press. 218p.

BRANDÃO-JUNIOR, D.S.; CARVALHO, M.L.M; VIEIRA, M.G.G.C. 1999. Variações eletroforéticas de proteínas e isoenzimas relativas à deterioração de sementes de milho envelhecidas artificialmente. Revista Brasileira de Sementes, Brasília, v.21, p. 114-121.

BRASIL. 2009. Ministério da Agricultura, Pecuária e Abastecimento. Regras para análise de sementes. Brasília. 399p.

CARVALHO, N.M.; NAKAGAWA, J. 2000. Sementes: ciência, tecnologia e produção. Jaboticabal: Funep, 4. ed. $588 \mathrm{p}$.

DHINGRA, O.D. 1985. Prejuízos causados por microorganismos durante $\mathrm{O}$ armazenamento de sementes. Revista Brasileira de Sementes, Brasília, v.7, p. 139-145.

DINIZ, K.A.; OLIVEIRA, J.A.; SILVA, P.A.; GUIMARÃES, R.M.; CARVALHO, M.L.M. 2009. Qualidade de sementes de alface enriquecidas com micronutrientes e reguladores de crescimento durante o armazenamento.
Revista Brasileira de Sementes, Londrina, v.31, p. 228-238.

FERREIRA, D.F. 2000. Análises estatísticas por meio do SISVAR para windows versão 4.0. pp. 225-258. In: Proceedings from Reunião Anual da Região Brasileira da Sociedade Internacional de Biometria, 45, São Carlos. Anais. São Carlos: UFSCAR. p. 225-258.

FUNGUETO, C.I.; PINTO, J.F.; BAUDET, L.; PESKE, S.T. 2010. Desempenho de sementes de arroz irrigado recobertas com zinco. Revista Brasileira de Sementes, Londrina, v.32, p. 117-123.

HENNING, A.A.; FRANÇA NETO, J.B.; KRZYZANOWSKY, F.C.; COSTA, N.P. 2003. Avaliação de corantes, polímeros, pigmentos e fungicidas para o tratamento de sementes de soja. In: XIII Congresso Brasileiro de Sementes, 2003, Londrina. Informativo ABRATES, Londrina, v.13, p.234.

LIMA, L.B.; SILVA, P.A.; GUIMARÃES, R.M.; OLIVEIRA, J.A. 2006. Peliculização e tratamento químico de sementes de algodoeiro (Gossypium hirsutum L.). Ciência e Agrotecnologia, Lavras, v.30. n.6, p.1091-1098.

LINDSAY, W.L. 1972. Inorganic phase equilibria of micronutrients in soils. In: Mortvedt, J.J., Giordano, P.M., Lindsay, W.L. (Eds.). Micronutrients in agriculture. Madison: Soil Science Society of America. p. 41-57.

MALAVOLTA, E. 2006. Manual de nutrição mineral de plantas. Viçosa: UFV, $631 \mathrm{p}$.

MARSCHNER, H. 1995. Mineral nutrition of higher plants. 2. ed. New York: Academy Press. 887 p.

OHSE, S.; MARODIM, V., SANTOS, O.S., LOPES, S.J., MANFRON, P. A. 2000. Germinação e vigor de sementes de arroz irrigado tratadas com zinco, boro e cobre. Revista da Faculdade Zootecnia, 
Veterinária e Agronomia, Uruguaiana, v.7, p. 73-79. 2000.

REIS, E.M.; BENIN, F.J.; MEGGIOLARO, E.; FANTINI, S. 2005. Uso de polímeros no tratamento de sementes. In: Anuário ABRASEM 2005. Associação Brasileira de Sementes e Mudas, Pelotas. p.38-39.

REIS, E.M.; CASA, R.T. 1998. Patologia de sementes de cereais de inverno. Passo Fundo, Aldeia Norte Editora, 88p.

SANTOS, C.M.R.; MENEZES, N.L.; VILLELA, F.V. 2004. Alterações fisiológicas e bioquímicas em sementes de feijão envelhecidas artificialmente. Revista Brasileira de Sementes, Pelotas, v.26, p. 110-119.

SCANDALIOS, J.G. 1969. Genetic control of multiple molecular forms of enzymes in plants: a review. Biochemical Genetics, New York, v.3, p. 37-39.

TUNES, L.M.; BADINELLI, P.G; BARROS, A.C.S.A.; CASTRO, M.A.S. 2009. Alterações fisiológicas e enzimáticas em sementes de cevada sob diferentes condições de armazenamento. Magistra, Cruz das Almas, v.21, p. 154164.

TUNES, L.M.; PEDROSO, D.C.; MENEGHELLO, G.E.; CASTRO, M.A. S.; BARROS, A.C.S.A.; BADINELLI, P. G; MUNIZ, M.F.B. 2010. Perfil enzimático em sementes de cevada em resposta a diferentes concentrações salinas. Interciência, Caracas, v.35, p. 369-373.

VIEIRA, M.G.G.C.; VON PINHO, E.V.R.; SALGADO, K.C.P.C. 2006. Técnicas moleculares em sementes. Informe Agropecuário, Belo Horizonte, v.27, p. 88-96.

YAGI, R.; SIMILI, F.F.; ARAÚJO, J.C.; PRADO, R.M.; SANCHES, S.V.; RIBEIRO, C.E.R.; BARRETTO, V.C. M. 2006. Aplicação de zinco via sementes e seu efeito na germinação, nutrição e desenvolvimento inicial do sorgo. Pesquisa Agropecuária Brasileira, Brasília, v.41, p.655-660.

Recebido em: 26/11/2014 Aceito para publicação em: 17/9/2015 